\title{
CURRENT TRANSFORMATIONS OF BANKING MANAGEMENT: STRATEGIC ANALYSIS OF EXTERNAL FACTORS OF DIRECT INFLUENCE ACTIVITIES
}

The banking system of any country plays an extremely important role in the functioning and development of the national economy, since it provides all sectors and industries with financial resources, organizes settlements between different entities and turns cash and savings into capital. The stable activity of the banking sector is the key to the structural adjustment of the economy and its integration into the world economic space. Considering such a close connection of the banking system with other sectors of the economy, its activities are objects of the influence of numerous external factors and circumstances. The main system-forming element of the banking sector is an ordinary commercial bank, which management is the subject of numerous studies and scientific discussions. Recently, international banking practice has witnessed a transformation of approaches to banking management towards strategic management, which involves the process of long-term management of the bank with the formation of a general development strategy and objectives and goals of its achievement, and also considers the influence of factors of the external and internal environment. The correct approach to building a system of strategic management in a bank will not only improve the competitive position in the market and performance results but is a guarantee of banking stability in general. This article is devoted to one of the initial stages of strategic management - a strategic analysis of the external environment of a commercial bank, aimed at allocating quantitative factors of direct influence. It should be noted that external factors of direct influence are primarily concerned with entities that are directly related to banking institutions and which can be partially controlled. These included government agencies (controlling or having an impact on the banking sector), suppliers (which ensure the receipt of relevant financial, labor, material, information resources, etc.), consumers (clients of banking institutions), competitors (that is, other banking or credit institutions that provide similar services) and other counterparties. In each block, the main quantitative indicators were highlighted and a thorough analysis of their dynamics in recent years has been provided. The formed base is the basis for further research in this field.

Keywords: banking activities, strategic management of the bank, strategic analysis, external environment, factors of the direct influence.

Introduction. The banking system of Ukraine is currently in a process of reform and reconstruction, which has led to a significant reduction in the number of commercial banks in the system. In addition, there are significant changes in the financial sector and in the policy of the National Bank of Ukraine. All this leads to the need to review existing models of bank management and the application of new and more advanced forms, methods and principles. In this context, the application of the concept of strategic management extends that allows adapting timely to predicted and unpredicted changes, to adjust the strategy of development of a banking institution and an action plan, to make appropriate management decisions, to use the available resources and competitive advantages rationally and to prevent possible losses. It is precisely agreed strategic management that is a prerequisite for the development of innovations in banking activities and achievement of the set goals.

Recent research and publications analysis. The fundamental theoretical foundations of the concept of a strategic management and its constituent elements were formed in the works of such researchers as Ansoff I. (Ansoff H. I., 1984, 1989, 1999), Cassels E. (Cassels E., 2000), Carloff B. (Carlof B., 1991), 
Mintzberg H. (Mintzberg H., Ahlstrand B., Lampel J., 2001, Mintsberg G., Quinn JB, Goshall S., 2001), Pearce and Robinson (Pearce II JA., Robinson R.B. Jr., 1985), Thompson A., Strickland D. (Thompson A., Strickland J., 1998), Higgins J. (Higgins J.M., 1983), and others.

Rajnoha R., Lesníková P., Korauš A. (Rajnoha R., Lesníková P., Korauš A., 2016) investigated the peculiarities of a strategically oriented management by the business entities taking into account the connection with the sustainable development. Shahin P. (Shahin P., 2013) identified the key success factors in the implementation of the strategic management for the business entities. The work of Zizlavsky O. (Zizlavsky O., 2016), who explores the relationship between the management of the entity and its innovation activities, deserves attention.

The narrower studies on the application of the strategic management in the banking sector were conducted by the following researchers: Zarutska El. (Zarutska El., 2018), Buriak A., Lyeonov S., Vasylieva T. (Buriak A., Lyeonov S., Vasylieva T., 2015); considered the structural changes in the external environment; the question of the impact of innovation in banking activities on the state of the economy of different countries was the subject of research of N. Dovha and V. Boychenko (Dovha N., Boychenko V., 2017); the analysis of the effectiveness of the long-term banking activities taking into account the external and internal factors was conducted by Grmanová E. and Ivanová E (Grmanová E., Ivanová E., 2018); the assessment of the effectiveness of the banking management in the system of financial relations of stakeholders was conducted by H. Obeid, M. Brychko (Obeid H., Brychko M., 2017).

Despite the significant developments in this area, the issue of systematization of the main factors of the external environment that have a direct impact on the strategic management of the commercial bank in the changing conditions of Ukraine is paid insufficient attention.

Thus, the purpose of the article is to systematize the quantitative factors of the direct influence within the external environment, which determine the strategic management of the bank.

Research results. One of the first stages of the strategic management of the bank is a strategic analysis of the external environment and the factors of its influence.

It is rather conditionally to state that the external environment is outside of the investigated object (in our case - a banking institution), but it has a direct impact on its activities. It is from the external environment that most of the resources needed for the organization's life are supplied. It is generally accepted in the scientific literature to distinguish two main levels of the external environment: the micro level, represented by factors of the direct action, and the macro level, represented by the factors of indirect action.

Within the framework of this study, we propose to focus attention on the factors of the direct influence, which consist of agents that are directly related to banking institutions and which can be partially controlled. Typically, there are the following agents:

- government bodies, that is, structures that control or have an impact on the banking sector (first of all, the NBU and the direction of the monetary policy, as well as through indirect levers (through the fiscal policy, the state of the financial market, etc.));

- suppliers that provide the receipt of relevant resources (financial, labor, material, information, etc.) or services (marketing, insurance services, etc.) necessary for the institutions' operation;

- consumers, that is, clients of banking institutions (physical and legal persons) who use banking products and services;

- competitors, that is, other banking or credit and financial institutions that provide such services and constitute a competitive threat;

- other counterparties that have not been taken into account in the preceding subparagraphs but have a direct impact on the banking institution (for example, the public, the media, shareholders, authorities and other stakeholders).

The National Bank of Ukraine (hereinafter - the NBU) is the main state body that regulates banking 
activities and carries out banking supervision. The main function of the NBU is to ensure the stability of the monetary unit, as well as the price and financial stability, including the stability of the banking system (NBU, 1999). It is for this purpose that it conducts the monetary policy, the main course of which for the time being is the inflation targeting.

As stated in the General Principles of the Monetary Policy for 2018 and the Medium-term Perspective: "The medium-term inflation target (annual consumer price index growth) is set at $5 \%$ with an allowable range of deviations of \pm 1 p.p. and will be reached during 2018-2020" (NBU, 2017).

To achieve its goals, the NBU uses a variety of monetary instruments, among which a special place is occupied by the percentage policy. Let us consider the dynamics of the key interest rate of the NBU the discount rate, as well as the weighted average rates of refinancing on loans and deposits (Figure 1).

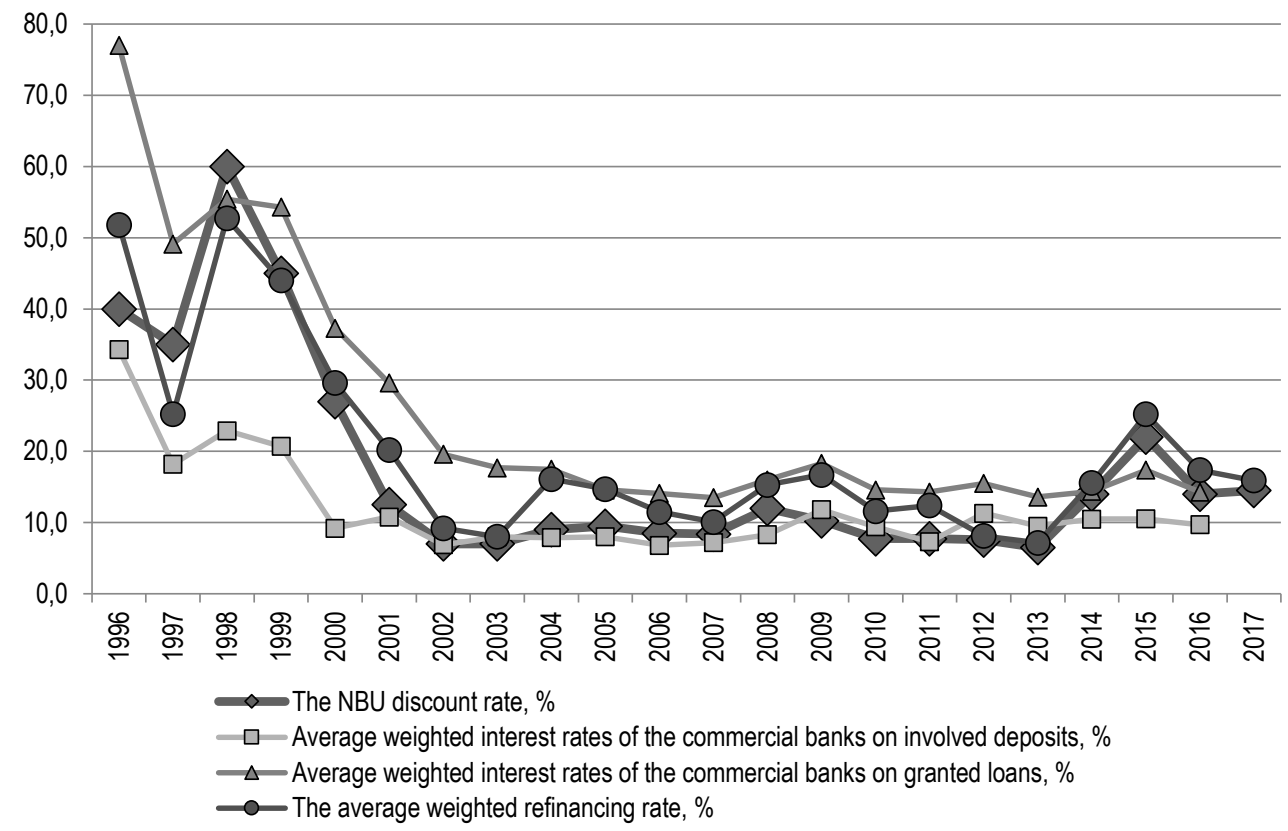

Figure 1 - The dynamics of the key indicators of monetary policy in Ukraine for 1996-2017 (the Statistical Base of the National Bank of Ukraine)

Changing the value of the discount rate also affects the interest rates of the commercial banks and is set by the NBU depending on general economic trends, macroeconomic indicators, etc. The largest interest rate in 1998 was due to the global financial crisis, after which it was gradually reduced to $7 \%$ in 2002. Thereafter, its fluctuations with a significant increase in crisis years $(12 \%$ in $2008,22 \%$ in 2015$)$ in line with the state of the money market and inflationary fluctuations. The dynamics of the discount rate development is a guide for both credit and deposit rates, the weighted average refinancing rate, which repeat the main trends of the development and are closely interrelated.

An equally important tool for the NBU to ensure price stability is the exchange rate policy, which aims to "create conditions for the development of a well-functioning, liquid and flexible currency market in Ukraine that has a high ability to self-balancing and absorbing shocks" (NBU, 2017). The main instrument here is the currency interventions of the NBU by buying or selling the currency on the interbank market. Their main tasks within the framework of monetary policy are: accumulation of international reserves; 

Influence Activities

smoothing of the functioning of the currency market; maintaining the transmission of a key interest rate as the main instrument of the monetary policy (NBU, 2017).

Let's consider the dynamics of changes in the indicators of the currency market of Ukraine for 19962017 (balance of the currency interventions, exchange rate and gold and currency reserves) in Figure 2.

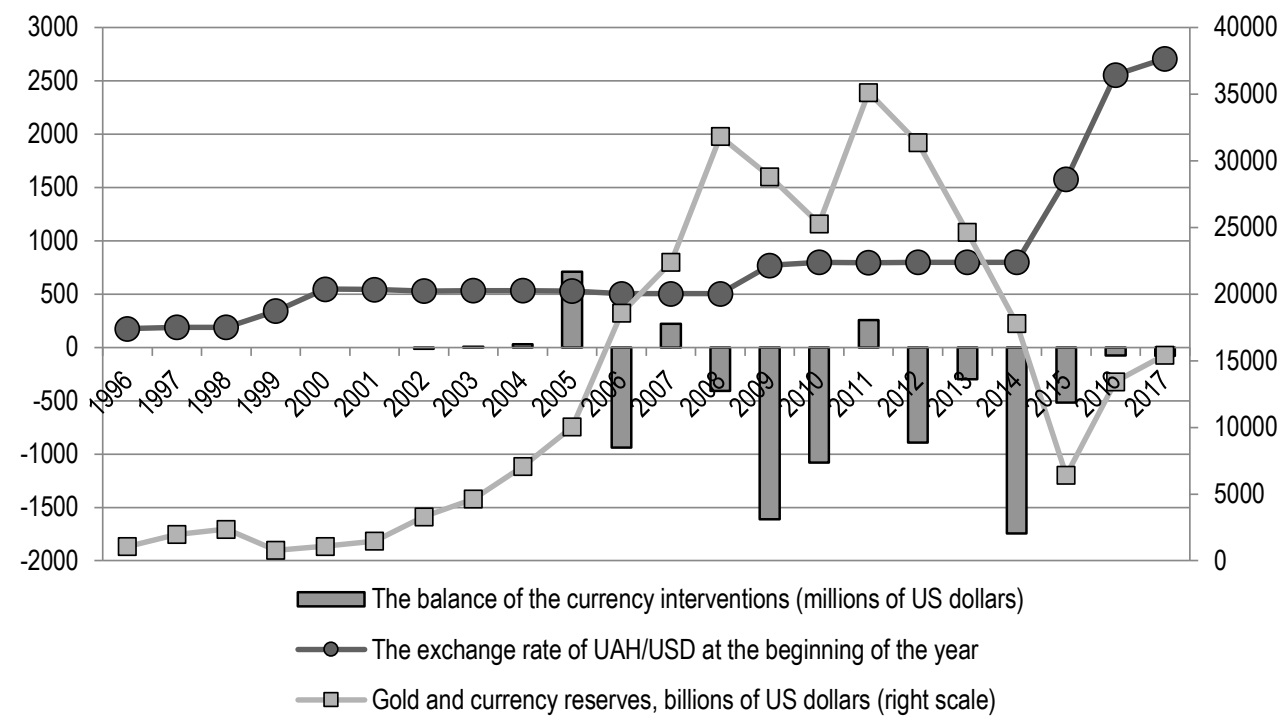

Figure 2 - The dynamics of the main indicators of the monetary policy in Ukraine for 1996-2017 (the Statistical Base of the National Bank of Ukraine)

The exchange rate of UAH/USD for the analyzed period had a general tendency to increase. Relative exchange rate stability was observed from 2000 to 2008, after which there was a significant devaluation of the hryvnia by $50 \%$ as a result of the global financial crisis. This led to significant negative currency interventions of the NBU and the reduction of gold and currency reserves.

From 2010 to 2015 there was a slight recovery of the country's economy, which was reflected in the stabilization of the currency market. However, the next crisis period contributed to the devaluation of the hryvnia almost doubled, and the course continues to grow, and at the beginning of 2017 it was 27.07 . The gold and currency reserves have fallen critically, due to the tight monetary policy and a significant external debt of the country.

To characterize the suppliers of a banking institution, it is necessary to determine the main resources necessary for their activities. Given the specifics of the banking sector, the most significant resources will be financial, and labor (skilled workers of banking institutions), material (premises, transport, equipment and machinery) and intangible (computer programmes, know-how, image, etc.) resources are of secondary importance. Another feature is that the suppliers of financial resources (other banks, legal entities and individuals) are at the same time the consumers of services (clients) (Kozmenko S. M., Shpig F. I., Voloshko I. V., 2010).

Let us dwell in more detail on the financial resources of the bank, which is understood as "... the totality of funds (own, involved, borrowed), which are at the disposal of the bank, is a source of its production and social development, used by it to carry out profitable operations in order to achieve high financial results" (Drogorub I. V., 2014). From this definition, one can immediately distinguish the main classification of 
financial resources of banks - by the source of formation. In addition, financial assets may be presented in the form of assets, liabilities and capital, as reflected in the balance sheet.

We will analyze the dynamics of the financial resources of the banking system of Ukraine in Figure 3.

Thus, we observe the growth of financial resources of the banking system for the analyzed period. The share of own funds in liabilities fluctuates within $10-15 \%$ and at the beginning of 2018 makes $11.8 \%$ of the total liabilities. In general, there is a tendency to increase the amount of the equity, which is related to the regulatory requirement to increase the minimum amount of authorized capital. The share of liabilities in recent years is gradually decreasing, which is primarily due to the outflow of deposits (especially longterm ones) and is due to the decrease in the level of people's trust.

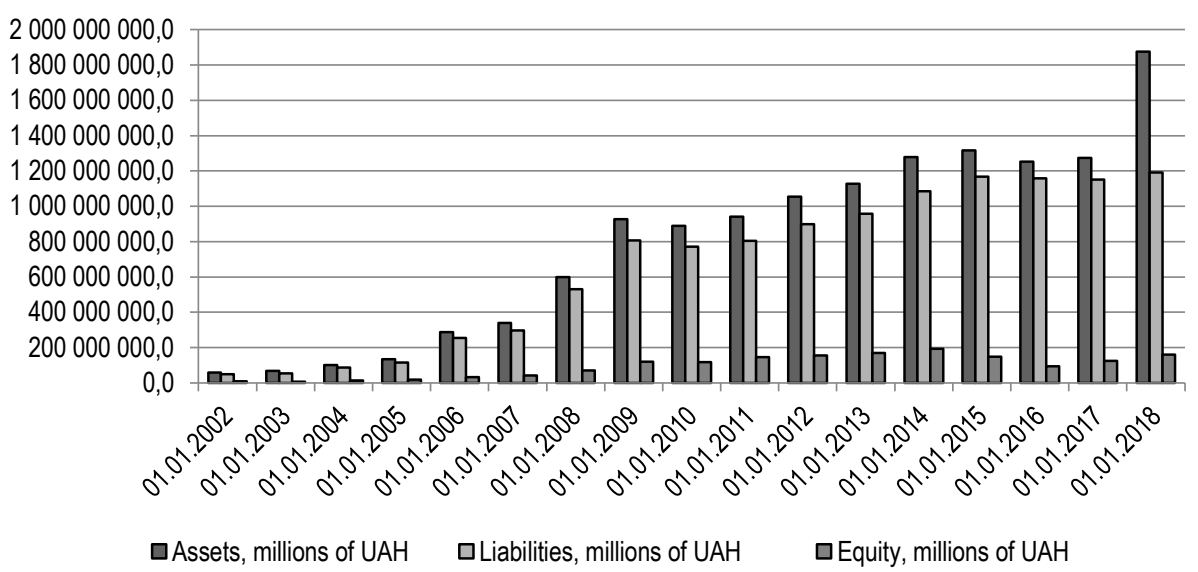

Figure 3 - The dynamics of the main indicators of financial resources of the banking sector of Ukraine for 2002-2018 (built by the author on the basis of the Statistical Base of the National Bank of Ukraine)

The next element of the external environment of the direct influence are consumers or customers whose characteristics depend on the specifics of the bank's activities, the range of products and services, the scale of activity, etc.

As the group of authors, headed by Kozmenko S.M., accurately points out, the success of the bank's strategic development is largely determined by the efficiency of the activity of attracting new clients, the content of which is as follows: attraction of existing clients to those types of services that they do not use in this bank by: improving the quality of service; attracting the attention of customers to novelties at the expense of use of price, preferential and other stimulating measures; forming the institute of new bank services; attraction of new clients not serviced by the bank by: servicing counterparties, partners, subsidiaries of existing clients, bank contractors; target campaigns; giving bonuses to bank employees as a result of attracting clients; attracting clients of bankrupt banks by obtaining part of debts; carrying out promotional activities, etc. [4].

A significant role in dealing with clients is played by a marketing strategy, the most common form of which is the Customer Relationship Management (CRM) tool. Its application allows: to carry out a comprehensive financial analysis of the bank's clients and classify them in terms of profitability; to create, analyze and systematize the bank clients (assessment of borrowers' creditworthiness, conducting the operational monitoring of the level and quality of demand for bank services); to develop new products and loyalty programmes based on accumulated and analyzed customer information based on the automation 

Influence Activities

and use of the latest Internet technologies, etc. (Kozmenko S. M., Shpig F. I., Voloshko I. V., 2010).

The next agent of the external environment of the direct influence are competitors represented by other banking or non-bank credit and financial, non-financial institutions that provide such services and constitute a competitive threat.

To analyze the competitive environment of the banking sector in Ukraine, we propose to assess the level of concentration of the banking market and the overall level of competition between commercial banks on it.

The Concentration Ratio (hereinafter CR) is one of the most well-known and simplest indices calculated as the percentage of market shares of banks by the main indicators: assets, capital, liabilities, etc. In the banking sector, these indicators are calculated for the leading three (CR3), five (CR5) and ten (CR10) banks by the formula (1):

$$
C R_{n}=\sum_{i=1}^{n} Y_{i}
$$

where $Y_{i}$ - the market share of the $i$-th bank

In addition, while studying the level of concentration of the banking system the Herfindahl-Hirschman Index (hereinafter $\mathrm{HHI}$ ) cannot be avoided, which is considered to be informative and practical and is recommended by the ICF to assess the level of concentration in the banking sector. Unlike the previous indicators, it characterizes the distribution of shares of the banking services market among all economic entities.

In general, it has the following mathematical expression (2):

$$
H H I=\sum_{k=1}^{N}\left(\frac{P_{k}}{P}\right)^{2}
$$

where $P_{k}$ - a certain indicator of the activity of a separate bank;

$P_{k}$ - the value of the relevant indicator for the entire banking system;

$N$ - the number of banks in the banking system.

Moreover, the following grading scale is allocated for the above-mentioned indicators of the concentration of the banking market (Table 2):

Table 2 - Characteristics of the market concentration on the grading scale (Wolfel J. J., 2000, Koretskaya N. I., 2014)

\begin{tabular}{|c|l|}
\hline Scale & \multicolumn{1}{|c|}{ Characteristics of the market } \\
\hline$C R 3<45 \%$ & Low-concentrated market \\
\hline $45 \%<C R 3<70 \%$ & Medium-concentrated market \\
\hline$C R 3>70 \%$ & Highly-concentrated market \\
\hline$C R 5(10)<40 \%$ & Low concentration and availability of a free competition \\
\hline $40 \%<C R 5(10)<60 \%$ & Medium concentration with a monopolistic type of competition \\
\hline $60 \%<C R 5(10)<80 \%$ & High concentration with oligopolistic competition \\
\hline$C R 5(10)>80 \%$ & Very high concentration which indicates a monopoly \\
\hline$H H I=0$ & Minimum concentration \\
\hline $0<H H /<0,1$ & Low concentration \\
\hline $0,1<H H K 0,18$ & Medium concentration \\
\hline$H H I>0,18$ & High concentration level \\
\hline
\end{tabular}

Let us consider the dynamics of the concentration level of the banking sector of Ukraine for 2002-2018 
by the size of assets, capital and liabilities in the figures.

Analyzing the graphs above, we note that there is a close relationship between the analyzed indices. In terms of the size of the assets and liabilities of the leading three banks, the banking market was characterized by a low concentration up to 2017, after which there was a transition to a medium concentration due to the reform of the banking sector and a significant reduction in the number of banks by merging their capital. For the top five and ten banks, there was a gradual transition from the free competition to the oligopoly, which is a positive sign for the Ukrainian banking system and its stability.

In order to assess the overall level of the competition in the banking sector of the world, the P-R model is widely used (Panzar, J.C. \& Rosse, J.N., 1987), що which reflects an assessment of the sensitivity of the bank's income to the prices of its resources.

Let us present the specification of the model in its general form (3):

$(i=1, \ldots n)$

$$
\ln \left(R_{i}\right)=\alpha+\beta_{1} \ln w_{1 i}+\cdots+\beta_{k} \ln w_{K i}+X_{i} \gamma+\varepsilon_{i}
$$

where $R_{i}$ - an income of a separate economic entity;

$\alpha, \beta, \gamma$-coefficients of the model;

$w_{K i}$ - prices for production factors;

$X_{i}$ - a vector of a control variable reflecting the separate characteristics of the economic entity; $\varepsilon-$ a random error value.

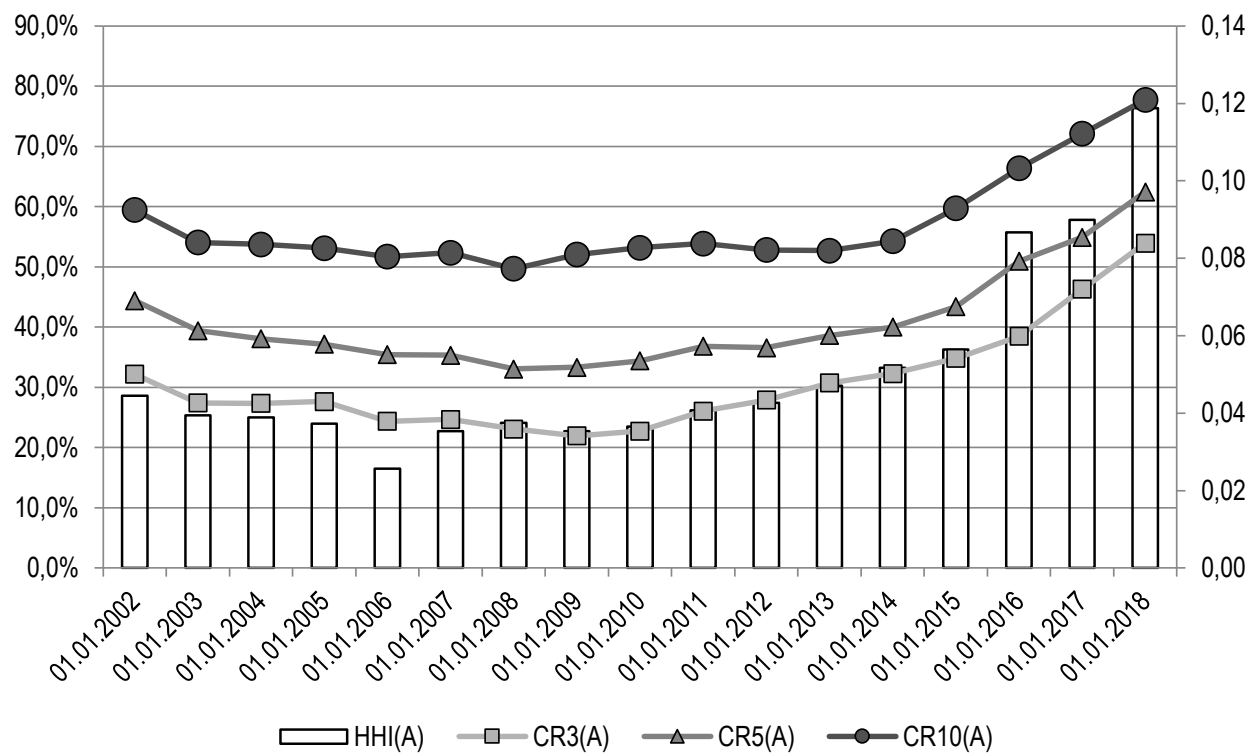

Figure 4 - The dynamics of the concentration of the Ukrainian banking market in terms of the size of assets for 2002-2018 (built by the author on the basis of the Statistical Base of the National Bank of Ukraine) 
T. Goncharenko. Current Transformations of Banking Management: Strategic Analysis of External Factors of Direct Influence Activities

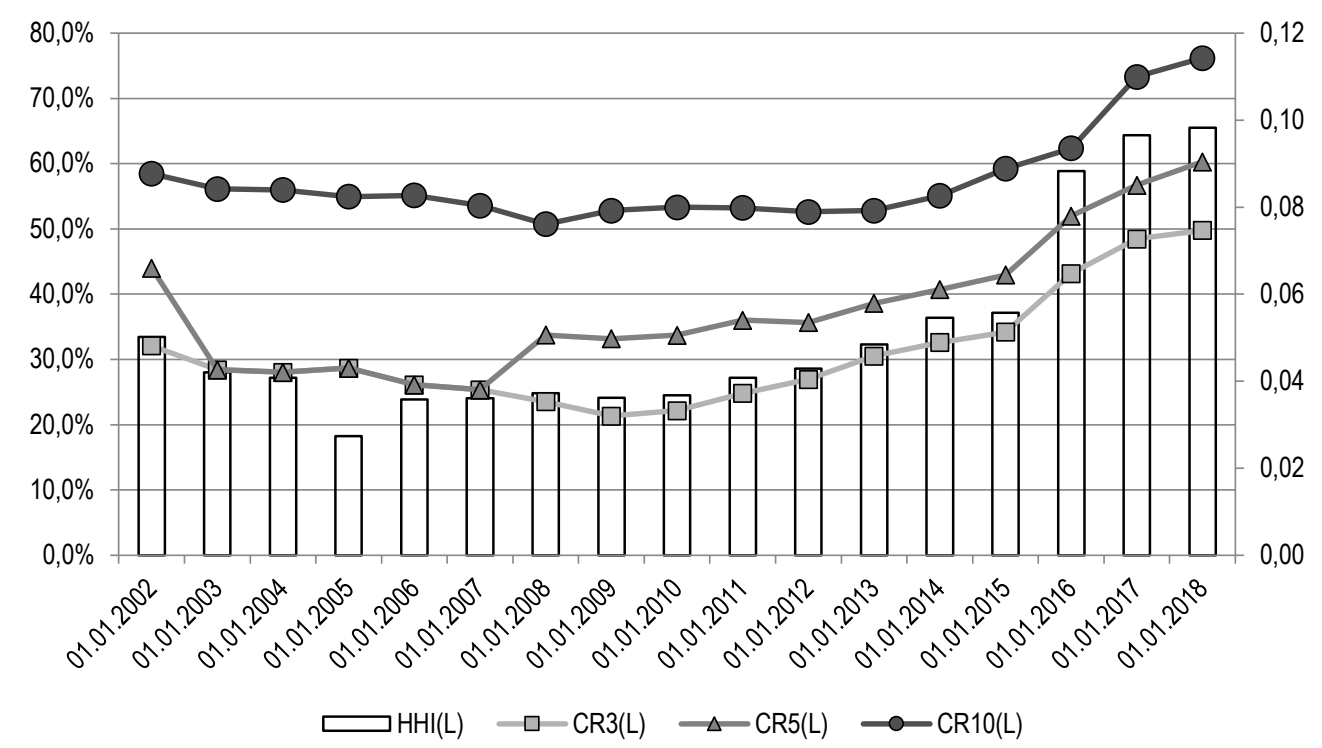

Figure 5 - The dynamics of the concentration of the Ukrainian banking market in terms of the commitments for 2002-2018 (built by the author on the basis of the Statistical Base of the National Bank of Ukraine)

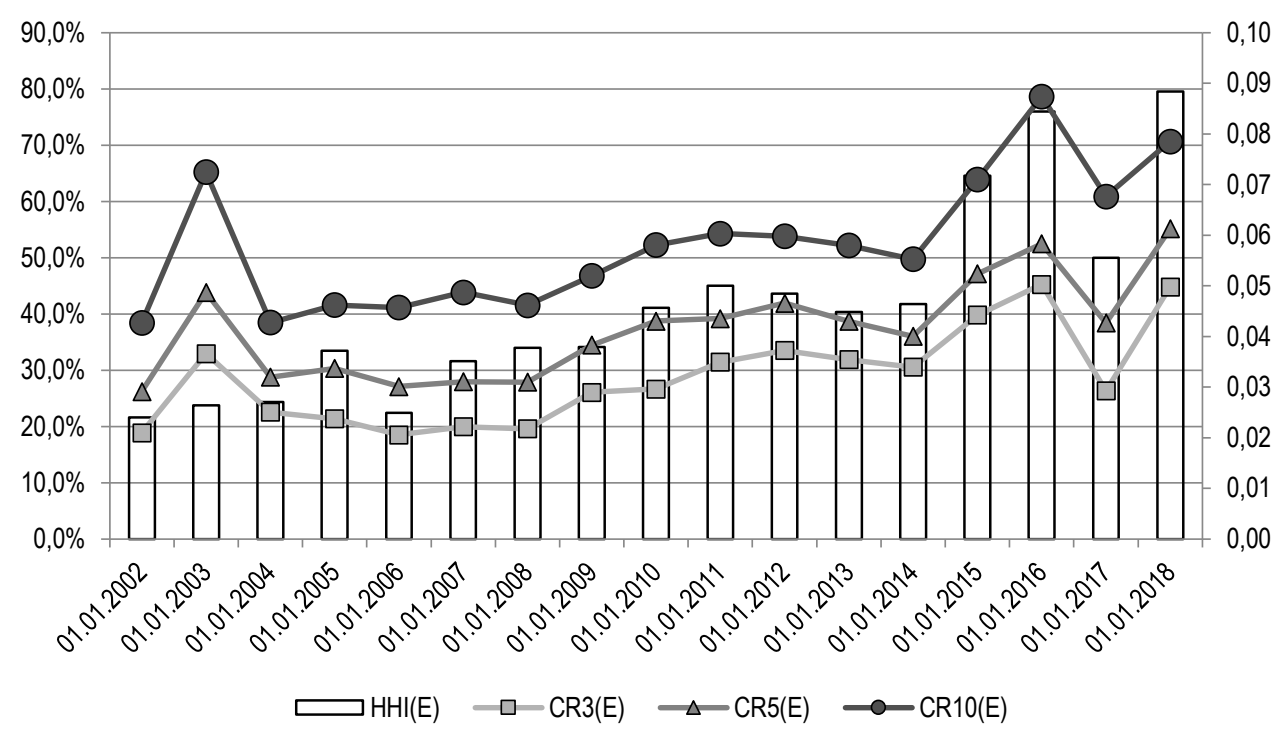

Figure 6 - The dynamics of the concentration of the Ukrainian banking market in terms of the size of the capital for 2002-2018 (built by the author on the basis of the Statistical Base of the National Bank of Ukraine)

Herewith, the $H$-statistics indicator will be equal to the sum of the coefficients of the model with the 
prices for production factors (4):

$$
H=\sum \beta_{k}
$$

The interpretation of this indicator takes place by the following scale:

Table 3 - The characteristics of the $\mathrm{H}$-statistics indicator by the Pansar-Rosa gradation scale (Panzar J.C. \& Rosse J.N., 1977, 1987)

\begin{tabular}{|l|l|}
\hline Scale & Characteristics of the market \\
\hline$H \leq 0$ & A perfect monopoly or a short-term oligopoly \\
\hline $0<H<1$ & Monopolistic competition with a free entry into the market \\
\hline$H=1$ & Perfect competition or a natural monopoly on an absolutely competitive market \\
\hline
\end{tabular}

To determine the $\mathrm{H}$-statistics indicator for the banking sector of Ukraine, we propose to choose the following specification:

$$
\ln \left(R_{i}\right)=\alpha+\beta \ln \left(F I P_{i t}\right)+\gamma \ln \left(B S F_{i t}\right)+\delta \ln \left(T A_{i t}\right)+\varepsilon
$$

where $R_{i}$ - the ratio of the interest income of the $i$-th bank to its total assets for the $t$ period;

$\alpha, \beta$-coefficients of the model; FIP $P_{i t}$ - prices for the production factors of the $i$-th bank for the $t$ period; $B S F_{i t}$ - specific banking factors of the $i$-th bank for the $t$ period; $T A_{i t}$ - total assets of the $i$-th bank for the $t$ period; $\varepsilon-$ a random error value.

Let us detail the indicators of the selected blocks of prices for the production factors, and the specific banking factors in Table 4.

Table 4 - The characteristics of the variables of the P-R model

\begin{tabular}{|c|l|l|l|}
\hline $\begin{array}{c}\text { Block of } \\
\text { factors }\end{array}$ & \multicolumn{2}{|c|}{ Indicators } & \multicolumn{1}{c|}{ Characteristics } \\
\hline $\begin{array}{c}\text { Prices for } \\
\text { Production } \\
\text { Factors (FIP) }\end{array}$ & FIP1 & Financial capital indicator & $\begin{array}{l}\text { The share of interest expense in the } \\
\text { borrowed funds }\end{array}$ \\
\cline { 2 - 4 } & FIP2 & $\begin{array}{l}\text { The indicator of the human and } \\
\text { physical capital }\end{array}$ & $\begin{array}{l}\text { The share of administrative and other } \\
\text { expenses in the assets }\end{array}$ \\
\hline \multirow{3}{*}{$\begin{array}{c}\text { Bank } \\
\text { Specific } \\
\text { Factors } \\
\text { (BSF) }\end{array}$} & BSF1 & $\begin{array}{l}\text { The indicator of the secondary } \\
\text { banking activity }\end{array}$ & $\begin{array}{l}\text { The share of the difference in a total } \\
\text { income minus an interest income in the } \\
\text { interest incomes }\end{array}$ \\
\cline { 2 - 4 } & BSF2 & Capital adequacy indicator & The ratio of the equity to the assets \\
\cline { 2 - 4 } & BSF4 & Credit activity indicator & The ratio of a loan portfolio to the assets \\
\cline { 2 - 4 } & DSF5 & $\begin{array}{l}\text { The indicator of the intensity of the } \\
\text { development of paid liabilities by } \\
\text { the banks }\end{array}$ & $\begin{array}{l}\text { The ratio of the paid assets to the paid } \\
\text { the liabilities }\end{array}$ \\
\cline { 2 - 4 } & liabilities \\
\cline { 2 - 4 } & BSF6 & $\begin{array}{l}\text { The indicator of non-working part of } \\
\text { assets }\end{array}$ & $\begin{array}{l}\text { The ratio of the unpaid assets to the } \\
\text { assets }\end{array}$ \\
\hline
\end{tabular}

The time period from 2003 to 2018 was chosen for the study, the financial statements of the NBU became the information base, and all banks that were present on the market at the time of the analysis became the object of the analysis. As a result of the regression analysis, the following regression equations 
T. Goncharenko. Current Transformations of Banking Management: Strategic Analysis of External Factors of Direct Influence Activities

were formed:

Table 5 - The results of the multiple regression analysis by the Pansar-Rosa method for the $H$ statistics determination

\begin{tabular}{|c|c|c|c|}
\hline Year & Regression equation & $R^{2}$ & $\mathrm{H}$-statistics \\
\hline 1 & 2 & 3 & 4 \\
\hline 2002 & $\begin{array}{l}\ln (R)=-0,83+0,57 \ln (F I P 1)+0,29 \ln (F I P 2)-0,12 n(B S F 1)- \\
-0,08 \ln (B S F 2)+0,45 \ln (B S F 3)-0,07 \ln (B S F 4)-0,38 \ln (B S F 5)+ \\
+0,18 \ln (B S F 6)-0,01 \ln \left(T A_{i t}\right)+0,15\end{array}$ & 0,71 & 0,86 \\
\hline 2003 & $\begin{array}{l}\ln (R)=1,12+0,52 \ln (F I P 1)+0,34 \ln (F I P 2)+0,05 \ln (B S F 1)+ \\
+0,12 \ln (B S F 2)+0,34 \ln (B S F 3)-0,34 \ln (B S F 4)-0,08 \ln (B S F 5)+ \\
+0,22 \ln (B S F 6)+0,01 \ln \left(T A_{i t}\right)+0,17\end{array}$ & 0,69 & 0,86 \\
\hline 2004 & $\begin{array}{l}\ln (R)=-1,02+0,67 \ln (F I P 1)+0,31 \ln (F I P 1)-0,42 \ln (B S F 1)- \\
-0,56 n(B S F 2)+0,37 \ln (B S F 3)-0,8 \ln (B S F 4)+0,54 \ln (B S F 5)+ \\
+0,12 \ln (B S F 6)-0,08 \ln \left(T A_{i t}\right)+0,32\end{array}$ & 0,72 & 0,98 \\
\hline 2005 & $\begin{array}{l}\ln (R)=-1,9+0,75 \ln (F I P 1)+0,18 \ln (F I P 2)-0,02 \ln (B S F 1)+ \\
+0,15 \ln (B S F 2)+0,25 \ln (B S F 3)-0,17 \ln (B S F 4)-0,14 \ln (B S F 5)+ \\
+0,16 \ln (B S F 6)-0,03 \ln \left(T A_{i t}\right)+0,19\end{array}$ & 0,78 & 0,94 \\
\hline 2006 & $\begin{array}{l}\ln (R)=-0,61+0,32 \ln (F I P 1)+0,28 \ln (F I P 2)-0,31 \ln (B S F 1)+ \\
+0,03 \ln (B S F 2)+0,39 \ln (B S F 3)+0,14 \ln (B S F 4)+0,44 \ln (B S F 5)+ \\
+0,101 \ln (B S F 6)-0,0 \ln \left(T A_{i t}\right)+0,242\end{array}$ & 0,72 & 0,65 \\
\hline 2007 & $\begin{array}{l}\ln (R)=1,08+0,69 \ln (F I P 1)+0,21 \ln (F I P 2)+0,008 \ln (B S F 1)+ \\
+0,09 \ln (B S F 2)+0,11 \ln (B S F 3)--0,21 \ln (B S F 4)-0,07 \ln (B S F 5)+ \\
+0,12 \ln (B S F 6)+0,08 \ln \left(T A_{i t}\right)+0,19\end{array}$ & 0,85 & 0,91 \\
\hline 2008 & $\begin{array}{l}\ln (R)=-0,89+0,75 \ln (F I P 1)+0,03 \ln (F I P 2)-0,06 \ln (B S F 1)- \\
-0,02 \ln (B S F 2)+0,18 \ln (B S F 3)+0,14 \ln (B S F 4)-0,05 \ln (B S F 5)+ \\
+0,01 \ln (B S F 6)-0,09 \ln \left(T A_{i t}\right)+0,21\end{array}$ & 0,72 & 0,78 \\
\hline 2009 & $\begin{array}{l}\ln (R)=-0,95+0,71 \ln (F I P 1)+0,006 \ln (F I P 2)-0,09 \ln (B S F 1)- \\
-0,05 \ln (B S F 2)+0,01 \ln (B S F 3)-0,16 \ln (B S F 4)-0,33 \ln (B S F 5)+ \\
+0,08 \ln (B S F 6)-0,21 \ln \left(T A_{i t}\right)+0,15\end{array}$ & 0,71 & 0,71 \\
\hline 2010 & $\begin{array}{l}\ln (R)=-1,14+0,29 \ln (F I P 1)+0,3 \ln (F I P 2)+0,16 \ln (B S F 1)+ \\
+0,13 \ln (B S F 2)+0,53 \ln (B S F 3)-0,13 \ln (B S F 4)-0,06 \ln (B S F 5)+ \\
+0,02 \ln (B S F 6)+0,002 \ln \left(T A_{i t}\right)+0,204\end{array}$ & 0,66 & 0,59 \\
\hline 2011 & $\begin{array}{l}\ln (R)=-1,53+0,41 \ln (F I P 1)+0,11 \ln (F I P 2)+0,07 \ln (B S F 1)+ \\
+0,18 \ln (B S F 2)+0,39 \ln (B S F 3)+0,01 \ln (B S F 4)-0,06 \ln (B S F 5)+ \\
+0,01 \ln (B S F 6)+0,1 \ln \left(T A_{i t}\right)+0,23\end{array}$ & 0,57 & 0,52 \\
\hline 2012 & $\begin{array}{l}\ln (R)=-1,28+0,48 \ln (F I P 1)+0,24 \ln (F I P 2)++0,15 \ln (B S F 1)+ \\
+0,22 \ln (B S F 2)+0,34 \ln (B S F 3)-0,34 \ln (B S F 4)-0,15 \ln (B S F 5)+ \\
+0,12 \ln (B S F 6)+0,08 \ln \left(T A_{i t}\right)+0,24\end{array}$ & 0,58 & 0,72 \\
\hline 2013 & $\begin{array}{l}\ln (R)=-1,24+0,58 \ln (F I P 1)+0,29 \ln (F I P 2)+0,02 \ln (B S F 1)+ \\
+0,24 \ln (B S F 2)-0,1 \ln (B S F 3)-0,19 \ln (B S F 4)-0,22 \ln (B S F 5)+ \\
+0,16 \ln (B S F 6)+0,14 \ln \left(T A_{i t}\right)+0,29\end{array}$ & 0,53 & 0,87 \\
\hline
\end{tabular}


Table 5

\begin{tabular}{|c|l|c|c|}
\hline 1 & \multicolumn{1}{|c|}{2} & \multicolumn{1}{|c|}{2} & \multicolumn{1}{|c|}{} \\
\hline 2014 & $\begin{array}{l}\ln (R)=-1,12+0,53 \ln (F I P 1)+0,37 \ln (F I P 2)+0,18 \ln (B S F 1)+ \\
+0,06 \ln (B S F 2)-0,09 \ln (B S F 3)-0,19 \ln (B S F 4)-0,27 \ln (B S F 5)+ \\
+0,22 \ln (B S F 6)+0,04 \ln \left(T A_{i t}\right)+0,28\end{array}$ & 0,61 & 0,90 \\
\hline 2015 & $\begin{array}{l}\ln (R)=-0,87+0,38 \ln (F I P 1)+0,39 \ln (F I P 2)+0,13 \ln (B S F 1)+ \\
+0,37 \ln (B S F 2)+0,08 \ln (B S F 3)-0,2 \ln (B S F 4)-0,2 \ln (B S F 5)+ \\
+0,25 \ln (B S F 6)+0,15 \ln \left(T A_{i t}\right)+0,34\end{array}$ & 0,81 & 0,78 \\
\hline 2016 & $\begin{array}{l}\ln (R)=-1,42+0,28 \ln (F I P 1)+0,36 \ln (F I P 2)-0,007 \ln (B S F 1)+ \\
+0,15 \ln (B S F 2)+0,24 \ln (B S F 3)-0,23 \ln (B S F 4)-0,24 \ln (B S F 5)+ \\
+0,13 \ln (B S F 6)+0,03 \ln \left(T A_{i t}\right)+0,33\end{array}$ & 0,54 & 0,63 \\
\hline 2017 & $\begin{array}{l}\ln (R)=-1,19+0,57 \ln (F I P 1)+0,35 \ln (F I P 2)-0,36 \ln (B S F 1)- \\
-0,2 \ln (B S F 2)+0,26 \ln (B S F 3)-0,3 \ln (B S F 4)-0,13 \ln (B S F 5)+ \\
+0,39 \ln (B S F 6)-0,06 \ln \left(T A_{i t}\right)+0,33\end{array}$ & 0,57 & 0,91 \\
\hline 2018 & $\begin{array}{l}\ln (R)=-0,77+0,56 \ln (F I P 1)+0,26 \ln (F I P 2)-0,18 \ln (B S F 1)- \\
-0,24 \ln (B S F 2)+0,08 \ln (B S F 3)+0,18 \ln (B S F 4)+0,24 \ln (B S F 5)+ \\
+0,31 \ln (B S F 6)-0,11 \ln \left(T A_{i t}\right)+1,27\end{array}$ & 0,56 & 0,82 \\
\hline
\end{tabular}

Based on the calculations of the level of competition by the Pansar-Rosa method, it can be stated that there was a monopolistic competition in the banking market of Ukraine with a free entry into the market.

One of the important factors in assessing the competitiveness of a particular industry is the analysis of the "entry" barriers. Thus, for the banking sector such barriers are:

- the need in the capital to cover the capital expenditures or initial investments needed to enter the banking market;

- -the formed image of already existing commercial banks and banking services on the regional banking market;

_ - -unequal competition conditions: a state support of some banks; the control of prices by the large commercial banks;

- -the general state of the socio-economic development of the country (for example, the low solvency of the population) and peculiarities of the regional market of the bank deposits (placement of small sums by individuals for urgent bank deposits, lack of long-term financial resources);

- -a lack of sufficient legal regulation, contradictory legislation of Ukraine, its tendency to change;

- $\quad$-the need to obtain a banking license (Shaida O. E., 2014).

Conclusions. A well-built system of strategic management of the bank is a guarantee of the success of the institution since it will allow adjusting the determined tasks and guidelines of activity depending on changing environmental conditions and adapt to possible changes in order to achieve strategic goals. That is why the strategic analysis of external factors of direct influence is one of the first stages of strategic management, which will allow making managerial decisions based on the results of the analysis of possible changes. In addition, direct influence factors can be partially controlled, which determines the value of information about them for planning future activities.

As a result of the conducted research, it was determined that the following factors are the main factors of the direct influence of the following groups of subjects. First of all, it is advisable to include the state bodies primarily in the person of the NBU, which, due to monetary policy, ensures the stability of the banking system. At the same time, during the research, the following quantitative factors were identified that could have a direct impact on the Bank's strategic management: the discount rate, the average 
weighted refinancing rates on loans and deposits, the balance of foreign exchange interventions, the exchange rate and gold and currency reserves.

Considering the group of suppliers, as the following subjects of direct influence, the most expedient to analyze the labor, material, intangible, financial resources of banks. The quantitative expression of financial resources is assets, liabilities and equity in general in the banking system.

The next subject of the factors of direct influence are consumers, whose quantitative expression is the customer base of banks (the number of open and closed accounts, balances on accounts, etc.) and their segmentation. It is from the successful interaction of banks with their clients that the results of their activities depend heavily.

Equally important and influential external factor is the competitive environment of banks proposed to be expressed by means of market concentration indicators (CR, Herfindahl-Hirschman Index (HHI)) and overall competition level (using Pansar-Rh's H-statistics).

The allocated quantitative parameters of the factors of direct influence are the basis of our research and will be placed in the further stage of work on the formalization of their impact on the results of the banking institution.

Ansoff H. I. (1989). Stratehyčeskoe upravlenye [Strategic management]. Sokr per. from english / ed. L. I. Evenko. M.: Economics. 519 p.

Ansoff H. I. (1999). Novaja korporatyvnaja stratehyja [New corporate strategy]. SPb : Publishing house "Piter". 416 p.

Ansoff H. I. (1984). Implanting strategic management. Prentice/Hall International, Englewood Cliffs, N.J. 510.

Bondarenko A. F., Rokoshna O. A., Kosenko V. I. (2013). Suchasni aspekty rozvytku klijentynh-stratehiji banku [Modern aspects of the client's strategy development of the bank]. Business Inform. No. 3. 313-318. URL: http://nbuv.gov.ua/UJRN/binf 2013358.

Buriak A., Lyeonov S., Vasylieva T. (2015). Systemically important domestic banks: an indicator-based measurement approach for the Ukrainian banking system. Prague Economic Papers. № 6. Vol. 24. 715-728.

Carlof B. (1991). Delovaja stratehyja: koncepcyja, soderžanye, symvolu [Business strategy: concept, content, symbols]. M.: Economics. 239.

Cassels E. (2000). Book 1. Introduction. Strategy. The Open University, Walton Hall, Milton Keynes. 432.

Dovha N., Boychenko V. (2017). Can banking innovations lead to new financial crisis: case of Central and Eastern Europe. Financial Markets, Institutions and Risks. Volume 1, Issue 2. 80-86.

Drogorub I. V. (2014). Vzajemozvjazok definicij «finansovi resursy banku», «resursy banku», «resursna baza banku» [Relationship between the definitions of "financial resources of the bank", "bank resources", "resource base of the bank"]. Scientific notes of the National University "Ostroh Academy". Series: Economics. V. 25. 104-108. URL: http://nbuv.gov.ua/UJRN/Nznuoa_2014_25_19.

Grmanová E., Ivanová E. Efficiency of banks in Slovakia: Measuring by DEA models. Journal of International Studies. №11(1). 257-272. - doi:10.14254/2071-8330.2018/11-1/20.

Higgins J.M. (1983). Organizational Policy and Strategic Management: Text and Cases, 2nd ed. Chicago: The Dryden Press.

Koretskaya N. I. (2014). Proces koncentraciji rynku bankivs'kyx posluh Ukrajiny: ocinka ta stratehiji pozycionuvannja [The Process of Concentration of the Ukrainian Banking Services: Assessment and Positioning Strategies]. Economic Forum. No. 1. 196204.

Kozmenko S. M., Shpig F. I., Voloshko I. V. (2010). Stratehichnyj menedžment banku [Strategic management of the bank]. Sumy: University book. $752 \mathrm{~s}$.

Mintsberg G., Quinn JB, Goshall S. (2001). Stratehyčeskyj process. [Strategic process]. Per. from english ed. Yu.N. Kaptuurevsky St. Petersburg: Peter. $688 \mathrm{~s}$.

Mintzberg H. Ahlstrand B., Lampel J. (2001). Shkolu stratehyj. [Schools of Strategies]. Series: theory and practice of management. SPb : Peter. 336.

Obeid H., Brychko M. (2017). Stakeholder's financial relations and bank business management efficiency: evidence from Ukraine. Financial Markets, Institutions and Risks. Volume 1, Issue 2. 12-29.

Panzar, J.C. \& Rosse, J.N. (1977). Chamberlin versus Robinson: An empirical test for monopoly rents. Bell Laboratories Economic Discussion Paper. No. 92.

Panzar, J.C. \& Rosse, J.N. (1987). Testing for "Monopoly" equilibrium. The Journal of Industrial Economics. 35(4). 443-456.

Pearce II JA., Robinson R.B. Jr. (1985). Strategic Management, 2nd ed. Homewood, III: Richard D. Irwin.

Pro Nacionalnyj bank Ukrajiny: Zakon Ukrajiny vid 20.05.1999 № 679-XIV. [About the National Bank of Ukraine: Law of Ukraine from 20.05.1999 № 679-XIV]. URL: http://zakon3.rada.gov.ua/laws/show/679-14. 
Pro Osnovni zasady hroshvo-kredytnoji polityky na 2018 rik ta serednostrokovu perspektyvu: rishennja NBU vid 12.09.2017 № 37-рд. [About the Basic Principles of Monetary Policy for 2018 and the Medium-Term Perspective: NBU decision from12.09.2017 № 37-pд]. URL: https://bank.gov.ua/doccatalog/document?id=55564681.

Rajnoha R., Lesníková P., Korauš A. (2016). From Financial Measures to Strategic Performance Measurement System and Corporate Sustainability: Empirical Evidence from Slovakia. Economics and Sociology. Vol. 9, № 4. 134-152. DOI: 10.14254/2071789X.2016/9-4/8.

Rats O. M., Toroeva V. O. (2016). Naprjamy udoskonalennja systemy formuvannja ta rozvytku klijents'koji bazy vitcyznjanyx bankiv [Directions of improvement of the system of formation and development of the client base of domestic banks] / O.M. Rat, /I Mukachevo State University. Economics and Society. №2. 599-604.

Shahin P. (2013). Key success factors of strategic management implementation in SMEs in Iran. Journal of International Studies. Vol. 6, №2. 65-78. DOI: 10.14254/2071-8330.2013/6-2/6.

Shaida O. E. (2014). Suchasnyj stan ta naprjamy rozvytku bankivskoji systemy Ukrajiny [Current state and directions of development of the banking system of Ukraine]. Scientific Bulletin of NLTU of Ukraine. Vol. 21.7. 204-206.

Thompson A., Strickland J. (1998). Stratehyčeskyj medežment. Yskusstvo razrabotky y realyzacyy. [Strategic Mediament. Art of design and implementation]. M.: Unity. $576 \mathrm{p}$.

Vasylieva, T., Lyeonov, S., Lyulyov, O., \& Kyrychenko, K. (2018). Macroeconomic stability and its impact on the economic growth of the country. Montenegrin Journal of Economics, 14(1), 159-170.

Wolfel J. J. (2000). Эncyklopedyja bankovskoho dela y fynansov [Encyclopedia of Banking \& Finance]. Samara: Fedorov Corporation. 559.

Zarutska El. (2018). Structural-functional analysis of the Ukraine banking system. Financial Markets, Institutions and Risks. №2(1). 79-96.

Zizlavsky O. (2016). The Use of Financial and Nonfinancial Measures within Innovation Management Control: Experience and Research. Economics and Sociology. Vol. 9, No 4. 41-65. DOI: 10.14254/2071-789X.2016/9-4/3.

T. П. Гончаренко, к.е.н., Сумський коледж економіки і торгівлі (Суми, Україна).

Сучасні трансформації банківського менеджменту: стратегічний аналіз зовнішніх факторів прямого впливу

Банківська система будь-якої країни відіграє надзвичайно важливу роль в функиіонуванні і розвитку національної економіки, адже вона забезпечує всі сектори та галузі фінансовими ресурсами, організовує розрахунки між різними суб'єктами господарювання та перетворює грошові кошти та заощадження в капітал. Стабільна діяльність банківського сектору є запорукою структурної перебудови економіки та її інтеграції у світовий економічний простір. Враховуючи такий тісний зв'язок банківської системи з іншими секторами економіки, її діяльність підпадає під вплие численних зовнішніх факторів та обставин. Основним системоутворюючим елементом банківської діяльності $є$ банківський менеджмент, дослідження управлінських аспектів в діяльності сучасних банкірів все частіше стає об'єктом численних досліджень та предметом для наукових дискусій. Останнім часом у міжнародній банківській практиці спостерігається трансформація підходів до банківського менеджменту в бік стратегічного управління, що передбачає процес довгострокового управління банком з формуванням загальної стратегії розвитку та завдань і цілей ї̈досягнення, враховує вплив фракторів зовнішнього і внутрішнього середовища. Правильний вибір системи стратегічного менеджменту в банку дозволить покращити конкурентну позицію на ринку й результати діяльності, $є$ запорукою стабільності діяльності банку загалом. Дана стаття присвячена одному з початкових етапів стратегічного менеджменту - стратегічному аналізу зовнішнього середовища банку, що спрямований на визначення кількісних факторів прямого впливу. Під зовнішніми факторами прямого впливу маються на увазі передусім суб'єкти, які мають безпосереднє відношення до банків та які можна частково контролювати. До них в ході дослідження було віднесено державні органи (що контролюють чи мають вплив на банківську сфреру), постачальників (які забезпечують надходження відповідних фрінансових, трудових, матеріальних, інформаційних ресурсів тощо), споживачів (тобто клієнтів банківських установ), конкурентів (тобто інші банківські чи кредитно-фінансові установи, які надають подібні послуги) та інших контрагентів. В кожному блоці було виділено основні кількісні показники та наведений грунтовний аналіз їх динаміки за останні роки. Сформована база є основою для подальших досліджень в даній сфрері.

Ключові слова: банківська діяльність, стратегічний менеджмент банку, стратегічний аналіз, зовнішнє середовище, фактори прямого впливу. 